\title{
France backs off promise to boost UN AIDS programme
}

Paris. The French government has reneged on a promise to donate FF100 million (US\$20 million) to the new joint United Nations Programme on HIV/AIDS known as UNAIDS - as part of broader cuts in foreign aid. The decision has provoked widespread protest in both France and elsewhere, as well as calls for it to be reversed.

The funding promise was made at last year's 'AIDS Summit' in Paris by then prime minister Edouard Balladur. Its apparent revocation has reinforced the views of sceptics that the meeting was largely a political stunt, as well as concern that support promised by political leaders at the meeting for the fight against AIDS would become a "long list of good intentions" that may never be translated into action (see Nature $372,308 \& 493 ; 1994$ ) .

Peter Piot, for example, the director of the UNAIDS programme, created late last year by five UN agencies and the World Bank as a replacement for the Global AIDS Programme of the World Health Organization (WHO), has described the French decision as "very worrying and profoundly disappointing".

One immediate consequence, according to Piot, will be the cancellation of series of planned programmes in developing countries. The full impact will not be known until later this week, when the programme's coordinating board meets to discuss its planned budget of $\$ 120-140$ million over the next two years.

One WHO official says that UNAIDS is confident that the programme will obtain the necessary commitments from donor countries. But the French decision - which WHO still hopes the French government will reverse in time for this week's meeting - will inevitably add to concern that UNAIDS may not obtain the financial and political support needed to accomplish its ambitious goals, particularly as it comes at a time when many industrialized countries are reducing their foreign aid budgets.

The pressure group AIDES, as well as several other French patient groups, have reminded the government that Balladur himself declared at the Paris summit that " 85 per cent of people infected with the AIDS virus live in disadvantaged countries", and says that "France would not be France any more, if it came to accept this situation".

Such protests have also been taken up forcefully by the newspaper Le Monde, which in a reference to the AIDS summit, declared in a leading article that "the deception is in line with the expectations created".

D. B.

\section{Geneticist quits in protest at 'genes and violence' claim}

Paris. The French president-elect of the Behaviour Genetics Association has resigned in protest at the refusal of the association's executive committee to expel a past-president for having given a speech in which he claimed that there was a racial basis for different murder rates between US cities.

The speech was given at the 25 th annual meeting last May of the 450-member association by Glayde Whitney, a psychologist at Florida State University. In the speech, Whitney argued that genetic inheritance may play a major role in determining behaviour and condemned what he described as the "left-liberal Marxist dogma of environmental determinism".

Presenting data which, he claimed, demonstrated a strong correlation between murder rates in US cities and the proportion of blacks, Whitney argued that "some, perhaps much" of this could be the result of genetic differences related to intelligence, "lack of empathy", aggression and "impulsive lack of foresight". He added: "I know of no environmental variable that accounts for more of the variation [than the proportion of blacks in the population]".

Many members of the both the association and the executive committee have since denounced the speech as "offensive". For example, the current president, James Wilson, of the University of Colorado's Institute for Behavioural Genetics, has described the address as hurtful both to black members of the audience and to black staff at the function, while the association's journal, Behaviour Genetics, has refused to publish the address.

But Whitney has now published his address in the journal Mankind Quarterly, accompanied by a preface entitled "Ideology and Censorship in Behaviour Genetics" in which he says that his speech was intended to show that "ideologically-based dogma and taboo" are hampering research in behavioural genetics.

Whitney, who is renowned for his work on olfaction in mice, was not available for comment last week. But in his preface, he described the reaction to his speech as a "parody of political correctness", and criticized members of the association's executive committee for acting in the "finest Lysenkoist tradition".

Despite such criticism, the executive committee has decided to take no action against Whitney. According to the association's secretary, Andrew Heath, of the department of psychiatry at the Washington School of Medicine in St Louis, Missouri, any action to penalize Whitney would be contrary to freedom of speech.
Furthermore, the committee, after consultations with former board members, cancelled a meeting scheduled to take place last week at which the issue of whether it would be "appropriate" to expel Whitney from the executive committee was to have been discussed. Holding the meeting would also only have "inflamed the situation", says Wilson, who himself had earlier urged Whitney to resign.

According to Heath, following these consultations, the committee concluded that Whitney had showed "poor judgement". But a majority of its members also felt that it could not "take the risk" of compromising the right of scientists to free speech. "The price we pay for this freedom is that sometimes we have to listen to things that might offend us an individuals," says Heath.

But Pierre Roubertoux, who was to have taken over as the association's president next year, disagreed, and announced that he

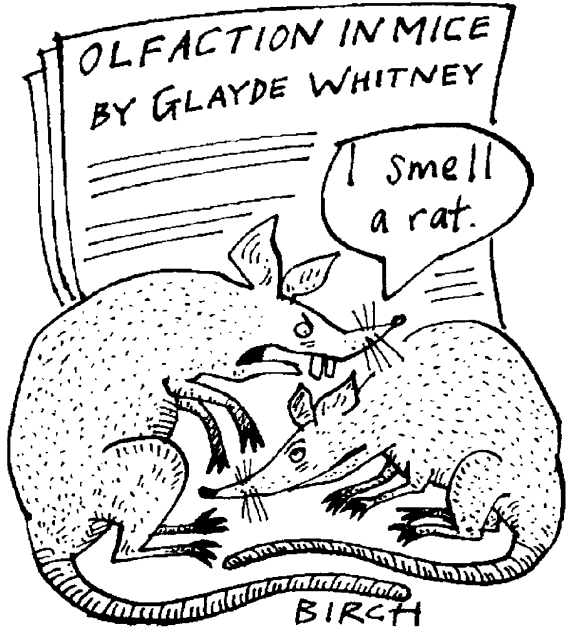

was no longer prepared to take up the new post - Roubertoux heads the Centre National de la Recherche Scientifique (CNRS)/University of Paris V René Descartes Laboratory of Genetics, Neurogenetics and Behaviour.

In his resignation letter, Roubertoux argues that freedom of speech should apply to a talk given as one individual's point of view at a symposium, where it could be discussed and if necessary challenged. But he claimed that, as the address was given by an elected officer, it appeared to be "the official view of the association".

Roubertoux, who walked out during Whitney's speech, says he has since apologised on the association's behalf to black waiters working at the function. "I refuse to be on the same board as Whitney," he adds. Wilson describes Roubertoux's resignation as a "heavy loss to the board."

Declan Butler 